UDC 625.85.06-022.532

Author: HELAL EZZAT, Graduate Student, Mansoura University, Public Works Engineering Department, Mansoura, Egypt, El Gomhouria Street, Dakahlia Governorate 35516, helo_ez@yahoo.com;

Author: SHERIF EL-BADAWY, Ph.D, Associate Professor, Mansoura University, Public Works Engineering Department, Faculty of Engineering, Mansoura University, Mansoura, Egypt, El Gomhouria Street, Dakahlia Governorate 35516, e-mail: sbadawy@mans.edu.eg;

Author: ALAA GABR, PhD, Assistant professor, Mansoura university, Public Works Engineering Department, Mansoura, Egypt El Gomhouria Street, Dakahlia Governorate 35516, eng-alaa1400@mans.edu.eg;

Author: SAAID I. ZAKI, Ph.D., Professor in Hosing and Building National Research Center HBRC, Cairo, Egypt ; Tahrir street, 87, dokki, Cairo, Egypt; 11511, Post box no 1770, saaid_zaki@yahoo.com

\title{
EVALUATION OF ASPHALT ENHANCED WITH LOCALLY MADE NANOMATERIALS
}

\section{Extended Abstract:}

This research work focused on the investigation of the properties of asphalt binder modified with different percentages of nanoclay (NC) and nanosilica. The nanosilica was manufactured from two different sources: silica fume (NSF) and rice husk (NSH). Results showed that NSF tends to decrease the penetration and increase the softening point temperature (SFT) and rotational viscosity (RV). However, NC content more than $3 \%$ was found to increase the penetration and decrease both RV and SFT. Using smaller percentages of NC increased both SFT and RV and decreased the penetration. Up to $3 \%$ of NSH exhibited improvement in penetration, SFT, and RV, however slight or no improvement was observed at higher contents. The Dynamic Shear Rheometer (DSR) results showed obvious improvement in the Superpave performance grade. Both NSF and NC were found to improve Marshall stability of the asphalt mixtures.

Key words: modified asphalt, nanomaterials, nanocaly, nanosilica, rotational viscometer, dynamic shear rheometer, marshall. 
MACHINE-REAdABLE INFORMATION ON CC-LICENSES (HTML-CODE) IN METADATA OF THE PAPER

$<$ a rel=»license» href=»http://creativecommons.org/licenses/by/4.0/» $><$ img alt=»Creative Commons License» style=»border width:0» src=»https://i.creativecommons.org/1/by/4.0/88x31.png» $/></ \mathrm{a}><$ br $/><$ span xmlns:dct=»http://purl.org/dc/ terms/» href=»http://purl.org/dc/dcmitype/Text» property=»dct:title» rel=»dct:type» $>$ Evaluation of asphalt enhanced with locally made nanomaterials $</$ span $>$ by $<$ a xmlns:cc=»http://creativecommons.org/ns\#» href=»Nanotehnologii v stroitel'stve = Nanotechnologies in Construction. 2016, Vol. 8, no. 4, pp. 42-67. DOI: dx.doi.org/10.15828/2075-8545-2016-8-4-42-67》 property=»cc:attributionName» rel=»cc:attributionURL»>Helal E., Sherif El-Badawy, Alaa G., Zaki S.I. $</$ a $>$ is licensed under $\mathrm{a}<\mathrm{a}$ rel=»license» $\mathrm{href}=» \mathrm{http}: / /$ creativecommons.org/licenses/by/4.0/» $>$ Creative Commons Attribution 4.0 International License $</ \mathrm{a}>$. $<$ br $/>$ Based on a work at $<$ a xmlns:dct=»http://purl.org/dc/terms/» href=»http://nanobuild.ru/en_EN/ nanobuild-4-2016/» rel=»dct:source»>http://nanobuild.ru/en_EN/nanobuild-4-2016/</a $>$. $<$ br $/>$ Permissions beyond the scope of this license may be available at $<$ a xmlns:cc=»http://creativecommons.org/ns\#»href=»saaid_zaki@yahoo.com» rel=»cc:morePermissions»>saaid_zaki@yahoo.com</a>.

\section{INTRODUCTION}

Just recently, several research studies in the field of highway and airport engineering, have been conducted to investigate the use of nanomaterials for asphalt modification [1-3]. Nanomaterials were found to improve asphalt and asphalt mixtures properties such as resistance to moisture damage, strength and stiffness, tensile strength, stability at higher temperatures, and noise reduction [4]. Nanomodified asphalts are quite different from asphalts modified with other materials (i.e., inorganic fillers). This is probably due to the fact that nanomaterials influence asphalt properties at microscopic level, which may bring superior properties into play, as reported by some researches [5-7]. Generally, conventional inorganic fillers are added in percentages varying between $20 \%$ and $40 \%$ by weight of the asphalt, however in nanocomposites a typical quantity of about $1 \%$ to $8 \%$ were reported in literature $[8,9]$.

Polymer modifiers such as styrene-butadiene rubber (SBR), styrenebutadiene-styrene (SBS), ethylene vinyl acetate (EVA), and polyethylene (PE) are examples of popular modifiers used to improve the ductility and/ or elasticity of the binder [9]. Polymer modified asphalt was developed also to improve pavement performance in terms of rutting, fatigue cracking and thermal cracking. However, only few of the produced polymers so far were satisfactory in terms of both the performance and the general cost [8]. On the other hand, the nanomodifiers are light weight and can enhance the mechanical behaviour and the thermal properties of the asphalt [8]. 
Most of the nanoparticles have very large specific surface area and great blending with asphalt concrete aggregate, which can improve the adhesion of asphalt [10]. When nanoparticles are dispersed in the asphalt uniformly, they act as enormous number of tiny aggregate particles leading to an increase in cohesion and viscosity of asphalt which in turn improves the performance of the modified binder at the high temperature conditions [10].

Number of studies have been conducted to evaluate the possibility of using nanosilica and nanoclay as modifiers to asphalt. In this review some pertinent studies are referred to. Literature studies showed that when 1\% to $2 \%$ silica fume was added to an asphalt cement it yielded a reduction in penetration and ductility and an increase in softening point, elastic strain recovery, and temperature susceptibility $[11,12]$. When doubling the percentages of silica fume, the penetration grade of the aged asphalt increased while the softening point decreased [13]. Thus higher percentages of silica fume are not recommended. According to a study by Mojtaba et al. [12], 2\% nanosilica was the optimum percentage to be added to the asphalt mixes along with $5 \%$ SBS to obtain the most improved mechanical behaviour. SBS and nanosilica were mixed in a two-roll mill at $50^{\circ} \mathrm{C}$ for 30 minutes. Both modifiers were then mixed with $60 / 70$ penetration grade asphalt with $48^{\circ} \mathrm{C}$ softening point and $+100 \mathrm{~cm}$ ductility by high shear mixer at $160^{\circ} \mathrm{C}$ and $3000 \mathrm{rpm}$ for an hour. The study showed that the indirect tensile strength (ITS) and tensile strength ratio (TSR) of a mix prepared using this binder increased with the increase in nanosilica content [12].

Sarsam [14] found that increasing the silica fume from $1 \%$ to $4 \%$ by weight of the asphalt binder yielded a significant increase in viscosity and softening point of the asphalt, while it decreased the penetration value, and the stiffness modulus. These results contradict the results reported in [13].

A study conducted by Van et al. [15] used 1.5\% nanoclay by weight of asphalt and found improved ageing resistance in the short and long term. Yazdani and Pourjafar [16] reported higher compressive strength according to ASTM C39 [17] and higher softening point values with higher nanoclay content. They used nanoclay contents of 2,3 , and $4 \%$. Incorporation of up to $5 \%$ nanoclay in asphalt binder was reported to lower the penetration value and increase the softening point $[15,18,19]$. Nanoclay commercial type Cloisite ( $3 \%$ and $6 \%$ ) was found to increase the stiffness of the 
asphalt [15]. The addition of $6 \%$ of commercial type Nanofill was found to improve the aging resistance of a 70/100 penetration grade binder in both the short and long terms [15]. El-Shafie et al. [19] added $2 \%, 4 \%, 6 \%$, and $8 \%$ nanocaly by the asphalt weight on a base asphalt with 64 penetration, $52 \mathrm{~cm}$ ductility, and $52^{\circ} \mathrm{C}$ softening point. The base asphalt was heated to $160^{\circ} \mathrm{C}$ and mixed at $2500 \mathrm{rpm}$ for three hours with the different nanoclay proportions. At $8 \%$ nanoclay content, the modified asphalt yielded a $12^{\circ} \mathrm{C}$ higher softening point temperature, $25 \%$ decrease in penetration value, and increase in kinematic viscosity value at $135^{\circ} \mathrm{C}$ by $222 \%$ and at $150^{\circ} \mathrm{C}$ by $145 \%$ [19]. Nazzal et al. [6] adopted the asphalt Performance Grade (PG 70-22M) and modified it by a Cloisite 20A nanoclay. The PG 70-22M was prepared using two modification percentages of $2 \%$ and $4 \%$ by weight of the binder. Nanoclay was found to enhance the stiffness and hardness of the asphalt binder at the investigated temperatures of 15,25 , and $35^{\circ} \mathrm{C}$ [6]. Mahdi et al. [7] used 3, 5, and 9\% of nanoclay by weight of the base asphalt binder with 80 penetration and $46.5^{\circ} \mathrm{C}$ softening point. The blend was prepared mechanically at a speed of $500 \mathrm{rpm}$ by adding about $1 \mathrm{~g} /$ minute of nanoclay gradually to the hot binder at a mixing temperature of $150 \pm$ $5{ }^{\circ} \mathrm{C}$. Results showed an increase in penetration of the aged binder with increasing the nanoclay concentration. The researchers also reported a significant increase in the binder complex shear modulus $\left(\mathrm{G}^{*}\right)$ and decrease in the phase angle $(\delta)$ with modification [7].

Tang et al. [20] conducted Marshall tests to evaluate the performance of nanoclay with SBS (NC/SBS) modified asphalt mixtures. Results showed that nanoclay can help SBS to be more effective modifier since NC/SBS mixtures yielded higher mechanical performance and lower moisture susceptibility for immersed Marshell stability than mixture modified with SBS alone.

\section{OBJECTIVES}

The main objective of this research is to evaluate the properties of a base asphalt binder and hot mix asphalt (HMA) mixtures modified with two different nanomaterials: nanoclay and nanosilica from two different sources. The specific objectives of the research are:

- Determine the optimum mixing time as well as the effect of cooling and reheating on the properties of the nanomodified asphalt. 
- Investigate the rheological properties and performance of the modified asphalts.

- Investigate the influence of the modified binder on the HMA properties by Marshall stability as well as moisture susceptibility.

\section{MATERIALS}

\section{Nanomaterials}

Three different nanomaterials; nanoclay (NC), nanosilica synthetized from silica fume (NSF) and nanosilica chemically processed from rice husk ash (NSH) were used in this study.

Commercial types of nanoclay and nanosilica are now widely used in asphalt research, however in ours, the used nanomaterials were locally manufactured. Nanoclay was manufactured by exfoliation of the bulk structural clay to clay nanosheet. NSF on the other hand was manufactured by the chemical processing of Sodium Silicate.

NC and NSF were both manufactured in the Photovoltaic laboratory in «Housing and Building National Research Center», Cairo, Egypt. NSH was manufactured at the Faculty of Science, Damanhur University, Egypt as part of a research study focused on producing nanosilica from rice husk ash [21].

\section{Asphalt Binder}

For the asphalt binder, Egypt still uses the conventional penetration grade for the asphalt binder characterization. Thus, the asphalt binder utilized in this research was pen 60-70 grade, which was obtained from the ElNasr Petroleum Company in Suez, Egypt. This is the typical binder grade commonly used for road construction in Egypt.

\section{EXPERIMENTAL WORK}

The conducted experimental work was divided into three major tasks:

I) material characterization;

II) determination of the optimum mixing time of nanomaterials with asphalt binder; 
III) testing the nanomodified asphalt binders and mixtures.

Following is a detailed description of these tasks.

\section{Material Characterization}

The three investigated nanomaterials were first characterized using the Transmission Electronic Microscopy (TEM) in their dry powder state. The TEM micro-images shown in Fig. 1-a to 2-c evaluates their practical size distribution. The TEM image presented in Fig. 1-a shows a particle

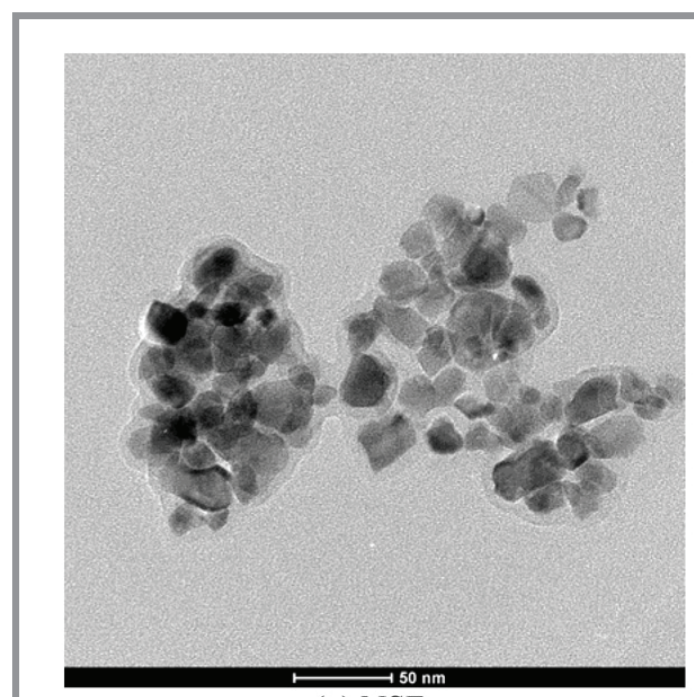

(a) NSF

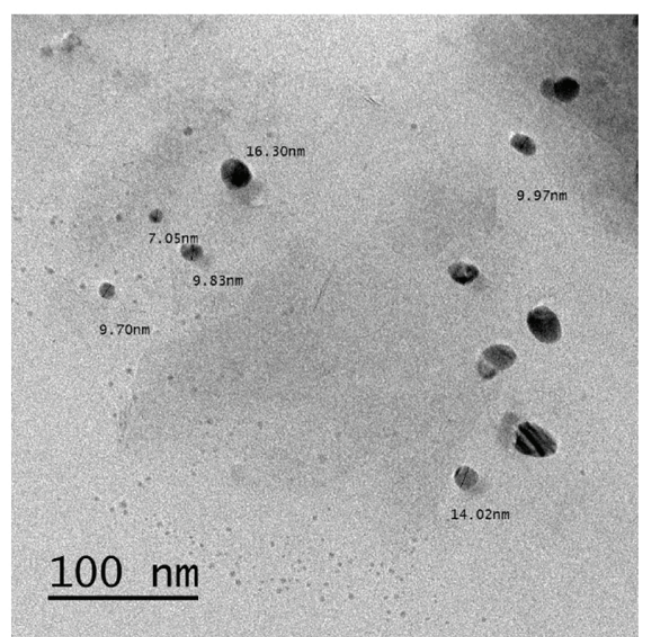

(b) NSH (Scale $100 \mathrm{~nm}$ )

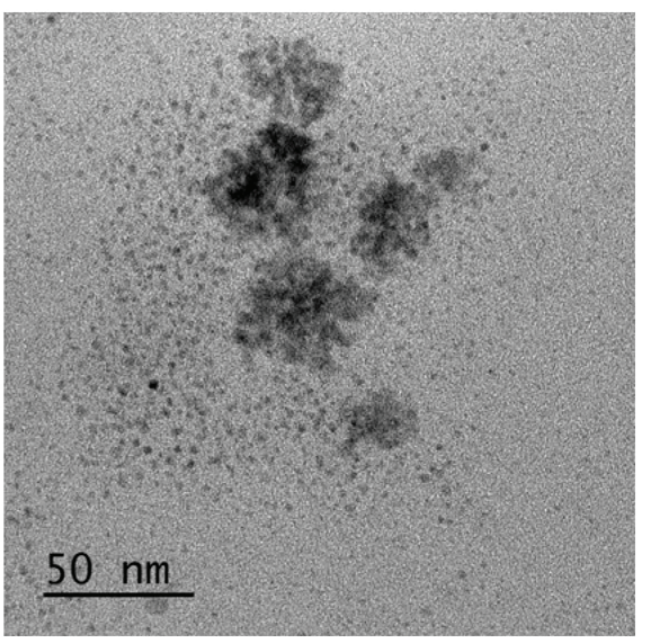

(c) $\mathrm{NC}$

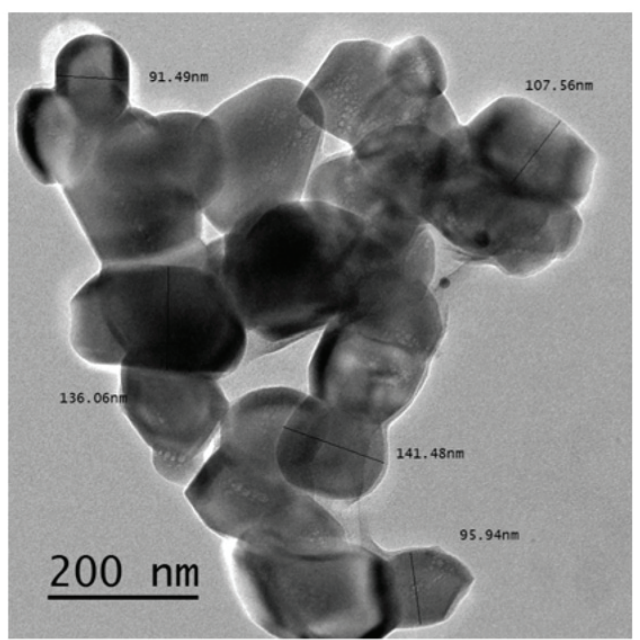

NSH (Scale $200 \mathrm{~nm}$ )

Fig. 1. Nanomaterials TEM Image 
Nanomaterials Rough Particle Size Distribution

\begin{tabular}{|l|c|c|c|c|}
\hline \multirow{2}{*}{$\begin{array}{c}\text { Nanomaterial } \\
\text { (color) }\end{array}$} & $\mathbf{5 \sim 1 5}$ & $\mathbf{1 5} \sim \mathbf{4 0}$ & $\mathbf{4 0} \sim \mathbf{1 0 0}$ & $>\mathbf{1 0 0}$ \\
\cline { 2 - 5 } $\begin{array}{l}\text { NC (light } \\
\text { cream) }\end{array}$ & $80 \%$ & $20 \%$ & $0 \%$ & $0 \%$ \\
\hline NSF (white) & $70 \%$ & $25 \%$ & $5 \%$ & $0 \%$ \\
\hline NSH (white) & $10 \%$ & $20 \%$ & $40 \%$ & $20 \%$ \\
\hline
\end{tabular}

size range of 9 to $25 \mathrm{~nm}$ for NSF. Fig. 1-b shows that most of NSH particles ranged from 15 to $50 \mathrm{~nm}$ with some particles exceeded the size limit of $100 \mathrm{~nm}$ to be considered as nanoparticles [22]. Finally, the NC particles sized down to $6 \mathrm{~nm}$ as shown in Fig. 1-c. However, the particles were found to cluster and form patches up to $100 \mathrm{~nm}$ in size as shown in Fig. 1-c. Table 1 summarizes the particle size distribution of the investigated nanomaterials extracted from the TEM images. This data shows that the investigated $\mathrm{NC}$ was much finer compared to the nanosilica.

Nanomaterials powder was also analyzed using the X-ray diffraction (XRD) and the results are shown in Fig. 2-a to 2-c. Both NSF and NSH peak were observed at $2 \theta \cong 22^{\circ}$. The highest intensity of the peak was much larger for NSH as shown in Fig. 2-a and Fig. 2-b. The NC peak was the largest at $2 \theta \cong 27^{\circ}$ with intensity of 150 counts as presented in Fig. 2-c.

To calculate the average crystallite size of the nanoparticles, DebyeScherrer diffraction formula shown by Equation (1) was used [23].

$$
D=\frac{k \lambda}{\beta \cos \theta},
$$

Where

$k=0.9$,

$\lambda=\mathrm{X}$-ray wavelength,

$\beta=$ full width at half peak height.

The computed values of the crystallite size were around $9 \mathrm{~nm}$ for NSF, $26 \mathrm{~nm}$ for NSH and $6 \mathrm{~nm}$ for NC. Fig. 2-b also showed some impurities in the NSH, indicating that it is not a pure Silicon dioxide. 


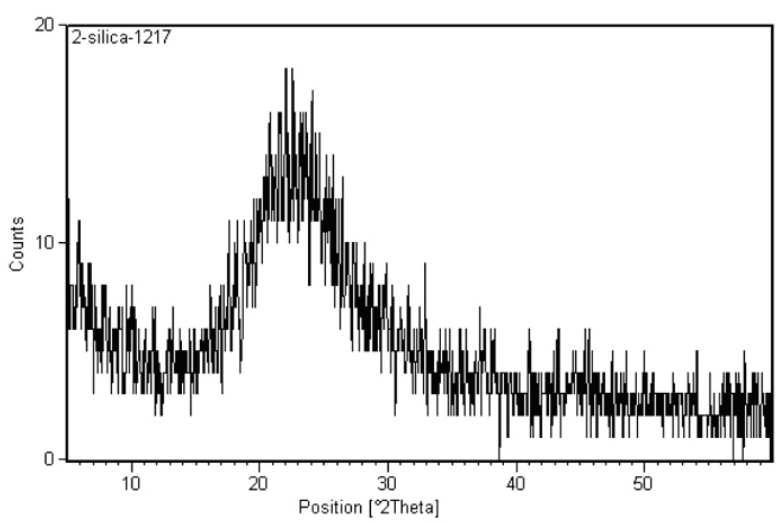

(a) NSF

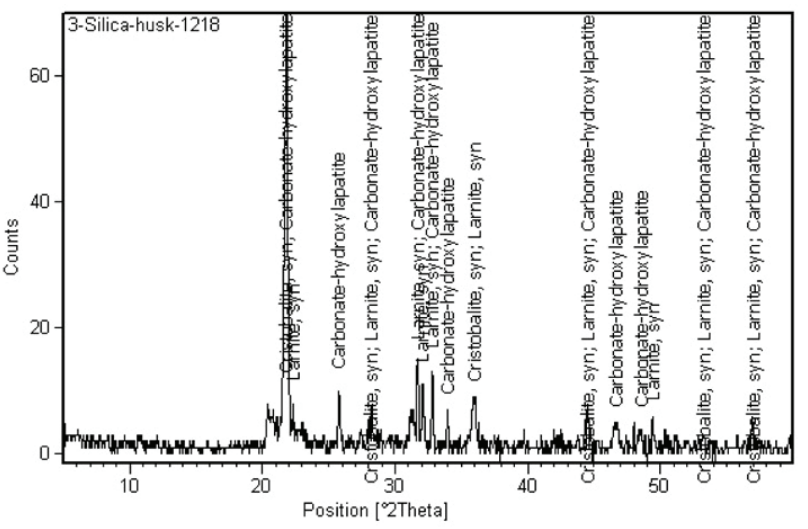

(b) $\mathrm{NSH}$

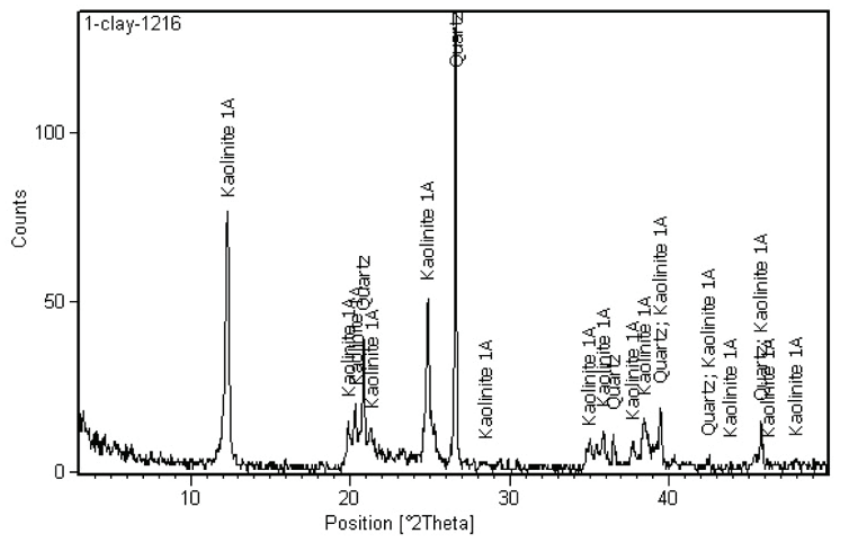

(c) $\mathrm{NC}$

Fig. 2. Nanomaterials XRD Image

For the asphalt binder, a control sample was tested first before adding any of the modifiers. This base binder (control) is referred to as $(0 \%)$ nanomaterial in this research. The basic properties of the base binder are given in Table 2. It can be surmised from the penetration value of the investigated binder that the base asphalt sample did not achieve the requirements of Pen 60/70 grade as specified by the Egyptian Code of Practice [24].

\section{Mixing Time Study}

Some nanomaterials are known to aggregate or cluster when mixed with the binder. Thus, it was important to select the appropriate mixing process in order to achieve a homogenous mixture of the asphalt and nano- 
Properties of the Base Asphalt

\begin{tabular}{|l|c|c|c|}
\hline \multicolumn{1}{|c|}{ Parameter } & Value & Test Method & Reference \\
\hline Penetration at $25^{\circ} \mathrm{C}(0.1 \mathrm{~mm})$ & 56 & ASTM D5-06 & {$[25]$} \\
\hline Ring and ball softening point $\left({ }^{\circ} \mathrm{C}\right)$ & 41.9 & ASTM D36-95 & {$[26]$} \\
\hline RV viscosity at $135^{\circ} \mathrm{C}(c P)$ & 391.7 & $\begin{array}{c}\text { ASTM } \\
\text { D4402M-15 }\end{array}$ & {$[27]$} \\
\hline RV viscosity at $165^{\circ} \mathrm{C}(c P)$ & 111.5 & $\begin{array}{c}\text { ASTM } \\
\text { D4402M-15 }\end{array}$ & {$[27]$} \\
\hline DSR performance grade $(P G x x)$ & 52 & ASTM D7175-08 & {$[28]$} \\
\hline
\end{tabular}

material. There are three different types of mixers that are commonly used to mix the nanomaterials with binders. These mixers are mechanical, high shear, and ultrasonic mixers [30]. In this research, a mechanical mixer with a $1500 \mathrm{rpm}$ speed was used. The mixing time was evaluated by mixing $5 \%$ of each of the investigated nanomaterials with the asphalt binder for $5,10,15$, $30,45,60$ and 75 minutes at a mixing temperature of $145^{\circ} \mathrm{C} \pm 5^{\circ} \mathrm{C}$. The Brookfield rotational viscosity (RV) at $135^{\circ} \mathrm{C}$ was selected for the mixing time evaluation as shown in Fig. 4.

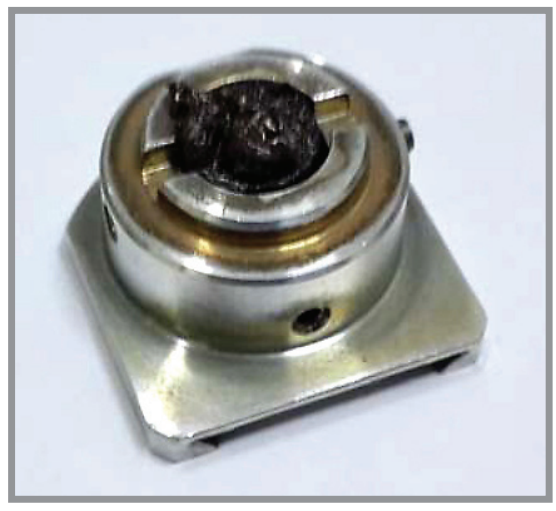

Fig. 3. Binder sample after SEM coating

Samples from the binder were taken after its modification by the nanomaterials as it is hot. The samples were then placed on the Scanning Electron Microscope testing beam.

The beam was then placed in the vacuum chamber and the binder was coated by coating material. The coating material interacted chemically with the binder and changed its dark black color to grey as shown in Fig. 3 . This may have affected the quality of the images.

SEM images were used to capture the mixing time effect as depicted in Fig.4. NSF modified asphalt reached about $97 \%$ of its maximum possible new viscosity of $670 \mathrm{cP}$ after 75 minute of mixing (due to the addition of $5 \% \mathrm{NSF}$ ) in about 45 minutes, while mixing for only 5 minutes yielded a viscosity that was about $65 \%$ of the maximum. The NSH modified asphalt 


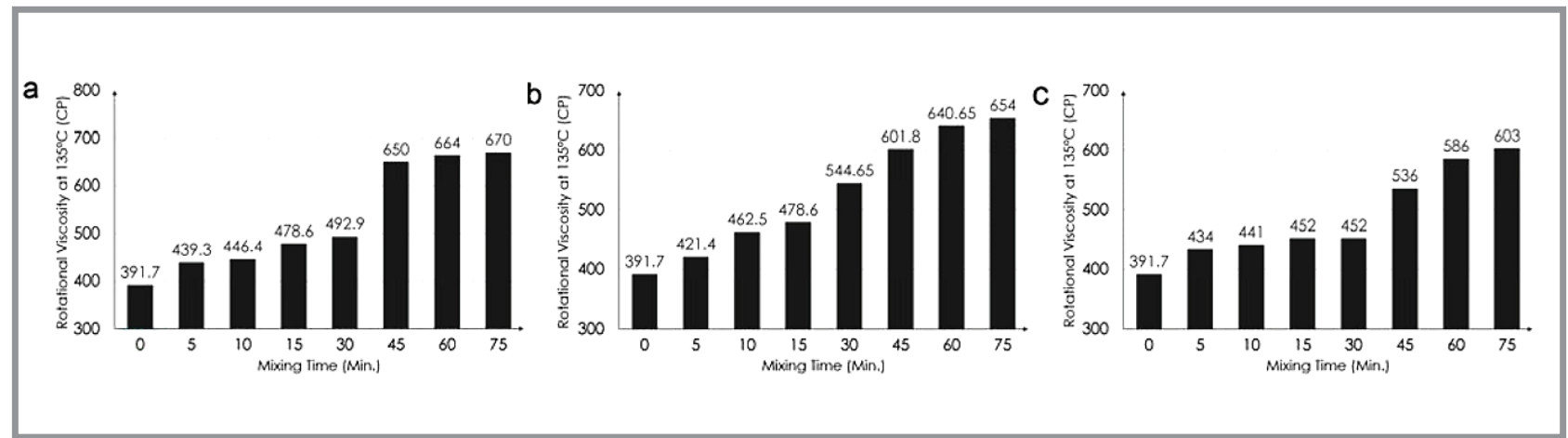

Fig. 4. Mixing Time Effect on Rotational Viscosity

reached $65 \%$ and $92 \%$ of the maximum $R V$ viscosity at 5 and 45 minutes, respectively. Finally, the NC modified asphalt needed an hour to reach $98 \%$ of the maximum $\mathrm{RV}$ viscosity, while it reached about $89 \%$ at 45 minutes. In 5 minutes, NC modified asphalt reached $72 \%$ of its maximum possible new viscosity.

SEM images shown in Fig.5-a to 5-c confirmed the RV results when comparing a sample after 5 and 60 minutes of mixing the nanomaterial with the asphalt binder. Nanomaterial pockets were seen very clearly when the mixing of NSF and NSH was for 5 minutes only as shown in Fig. 5-ai to 5-bi. On the other hand, after 60 minutes mixing time, pockets were rarely seen as shown in Fig.5-aii and 5-bii for NSF and NSH, respectively. For nanoclay some pockets were still seen though after 60 minutes of mixing as shown in Fig.5-cii. Based on the RV results and the SEM images for the mixing time study, it can be concluded that the optimum mixing time is around 45 minutes for nanosilica and 60 minutes for nanoclay. Thus, a mixing time of 60 minutes was adopted for mixing the nanomaterials with the binder before any testing.

\section{Testing the Modified Asphalt Binder}

Samples of the base asphalt binder were mixed with $3 \%, 5 \%$ and $7 \%$ of NC, NSF and NSH by weight of the binder for one hour at a mixing temperature of $145 \pm 5^{\circ} \mathrm{C}$. The $7 \%$ percentage, which is quite high specially when compared with previous studies, will give us a new indication to the asphalt behavior with high nanomaterials content. Penetration, softening point, RV viscosity and DSR tests were conducted on the original and modi- 
THE RESULTS OF THE SPECIALISTS' AND SCIENTISTS' RESEARCHES

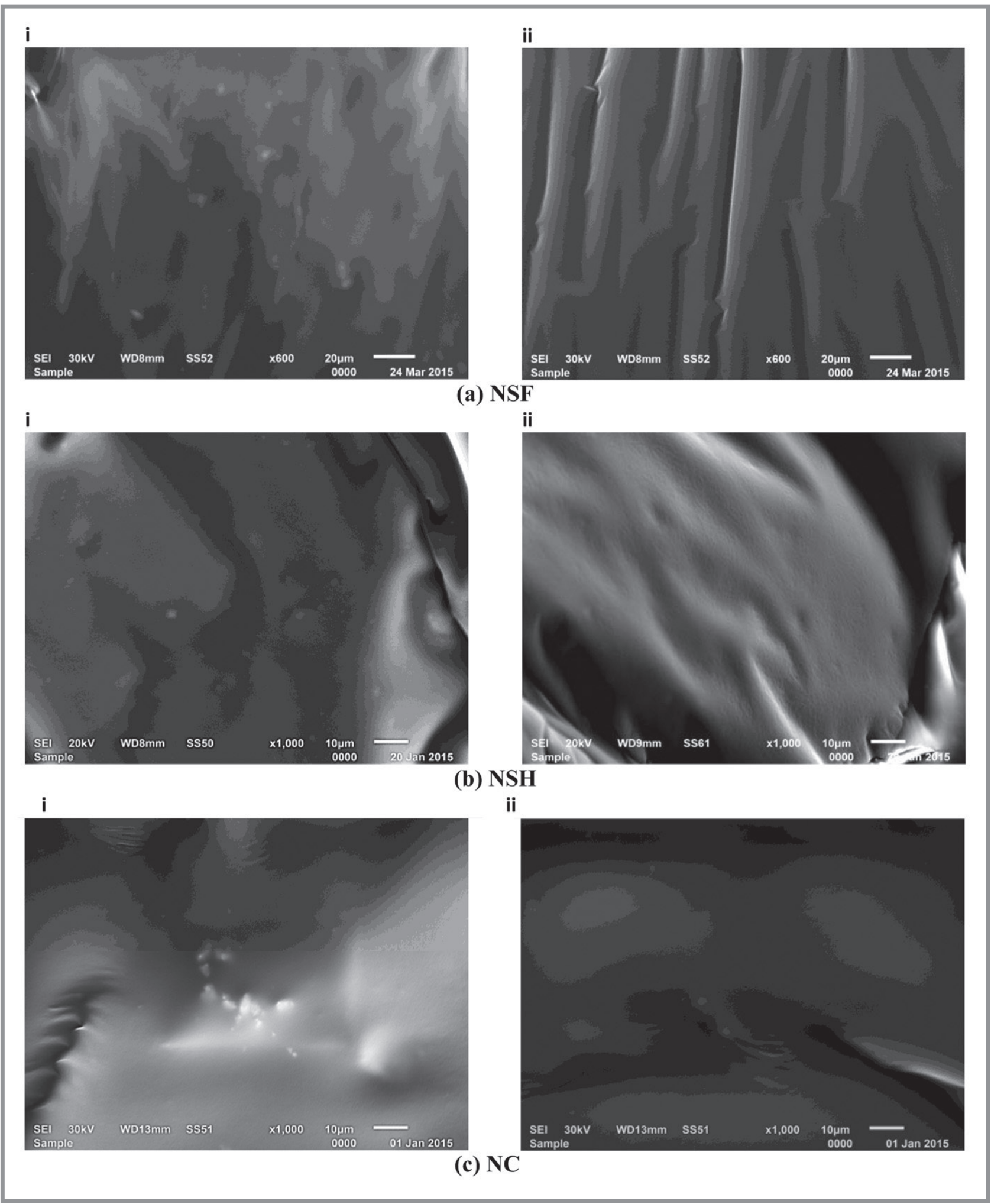

Fig. 5. SEM Images for Asphalt Modified at ( $i$ - after 5 minutes; ii - after 60 minutes) 
fied asphalts in accordance with the test methods given in Table 2. A range of testing temperatures of $135,145,155$ and $165^{\circ} \mathrm{C}$ was selected for the viscosity tests to evaluate the binder behavior over mixing and compaction temperatures. DSR tests were conducted over a range of field temperatures of $46,52,58,64,70$ and $76^{\circ} \mathrm{C}$ for both unaged and Rolling Thin Film Oven (RTFO) aged samples.

\section{Hot Mix Asphalt (HMA) Samples preparation and testing}

A mix design was prepared using Marshall design method, which is the current mix design method used in Egypt. The Optimum Binder Content (OBC) for this mix was found to be $5.5 \%$. The control HMA mixture was modified with $7 \%$ NSF and $3 \%$ NC (by weight of OBC). These percentages of the nanomaterials were selected as they yielded the best properties of the modified binders as explained in later. Marshall stability and flow, loss of stability, and indirect tensile (IDT) strength tests were performed on the prepared HMA mixtures. Marshall stability and loss of stability tests were performed in accordance with ASTM D6927 and ASTM D1559 [31, 32]. IDT tests and moisture susceptibility tests were conducted according to ASTM D1559 and ASTM D4867 [33, 34].

\section{RESULTS AND ANALYSIS}

\section{Effect of Heating, Cooling and Reheating on the Modified Asphalt}

In order to study the effect of asphalt cooling to room temperature after mixing with nanomaterials, patches of the modified binders were prepared and samples were tested for penetration, softening point, and viscosity at times of 1, 5 and 10 days from the mixing time. Nanomaterials were blended with hot liquid asphalt binder, then the binder was let to cool down to room temperature (about $18^{\circ} \mathrm{C}$ ). Specimens were then reheated again to a temperature up to the original mixing temperature of $145^{\circ} \mathrm{C} \pm 5^{\circ} \mathrm{C}$. No significant influence on the properties of the asphalt up to ten days from the first testing day was observed as given in Table 3. The data in this table exemplifies the impact of heating, cooling and reheating on the basic properties of the NSF modified asphalt. 
Table 3

Properties of the 5\% NSF Modified Asphalt Binder Over Time

\begin{tabular}{|l|c|c|c|c|}
\hline \multicolumn{1}{|c|}{ Test Name (unit) } & Day $\mathbf{1}$ & Day 5 & Day 10 & $\begin{array}{c}\text { Standard } \\
\text { deviation }(\sigma)\end{array}$ \\
\hline Penetration at $25^{\circ} \mathrm{C}(0.1 \mathrm{~mm})$ & 27 & 25 & 24 & 1.53 \\
\hline Softening point $\left({ }^{\circ} \mathrm{C}\right)$ & 46.3 & 47.5 & 48.0 & 0.87 \\
\hline $\begin{array}{l}\text { Rotational viscosity at } 135^{\circ} \mathrm{C} \\
\text { (poise) }\end{array}$ & 6.60 & 6.75 & 6.50 & 0.13 \\
\hline $\begin{array}{l}\text { Rotational viscosity at } 165^{\circ} \mathrm{C} \\
\text { (poise) }\end{array}$ & 1.60 & 1.66 & 1.63 & 0.03 \\
\hline
\end{tabular}

\section{Effect of Nanomaterial Type and Content on Binder Rheological Properties}

Fig. 5-a to 6-c show the influence of the nanomaterial type and content on penetration and softening point properties of the asphalt. Fig. 6-a shows a relatively linear relationship between the NSF percentage and penetration. The Fig. shows that a significant improvement in the penetration occurred with the increase in the modifier concentration. For the NSH modified binder, as the percentage of the modifier increased, a linear decrease in the penetration occurred till 5\% NSH. Adding more than 5\% NSH did not show a significant improvement in the penetration as shown in Fig. 6 -b. For NC, a decrease in the base asphalt penetration from 55.5 down to 33.3 at $3 \%$ concentration was found as shown in Fig. (5-c). Adding more $\mathrm{NC}$ did increase the penetration value afterwards up to 67 at $7 \% \mathrm{NC}$ by weight of the asphalt binder. For the softening point, both nanosilica types increased it from $41.1^{\circ} \mathrm{C}$ to more than $48.0^{\circ} \mathrm{C}$ as shown in Fig. 6-a and 5-b. $\mathrm{NC}$ increased the softening point up to $49.6^{\circ} \mathrm{C}$ at $3 \%$ then the values slightly decreased afterwards as shown in Fig. 6-c.

Fig.7-a to 7-c depict the impact of the nanomaterial content and temperature on Brookfield $\mathrm{RV}$ viscosity. At temperature of $135^{\circ} \mathrm{C}$, increasing the NSF and NSH to $7 \%$, increased the RV viscosity by $210 \%$ and $170 \%$, as shown in Fig. 7-a and 7-b, respectively. As the temperature increased, the influence of NSF presence was minimized to become as small as $16.6 \%$ at temperature of $165^{\circ} \mathrm{C}$. Fig. 7-b shows almost no improvement in viscosity 
THE RESULTS OF THE SPECIALISTS' AND SCIENTISTS' RESEARCHES

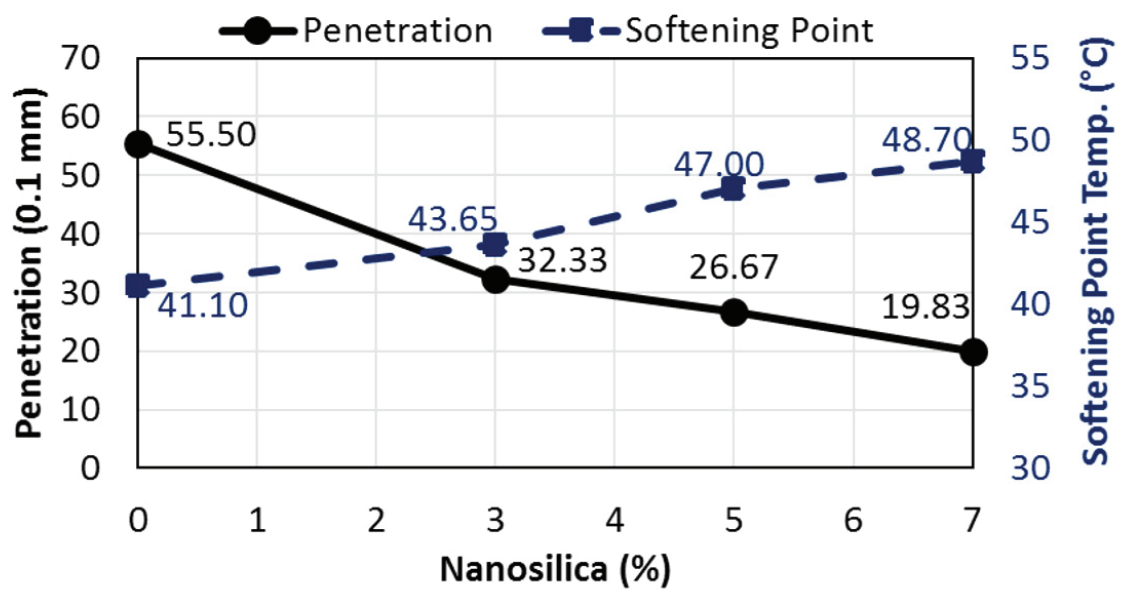

(a) NSF

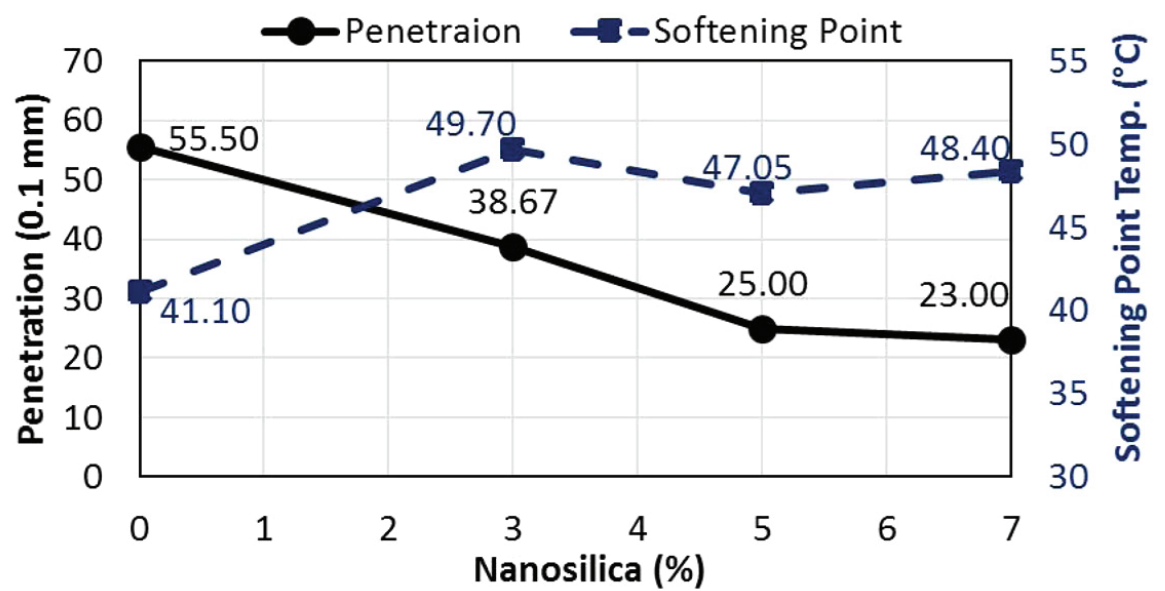

(b) NSH

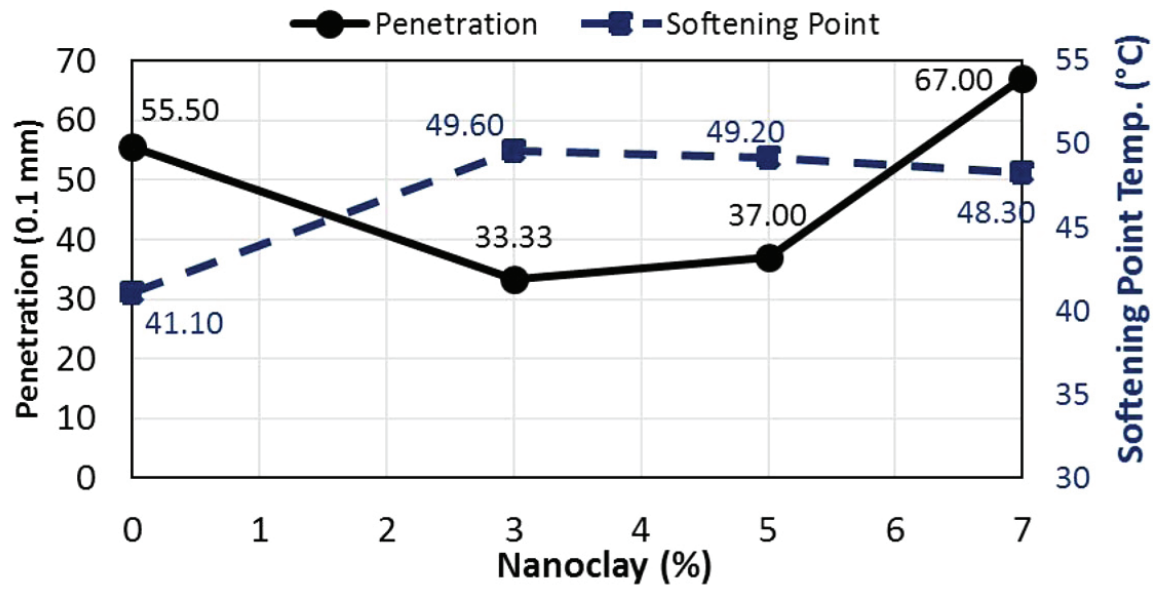

(c) $\mathrm{NC}$

Fig. 6. Effect of Nanomaterial Amount on Penetration and Softening Point 
THE RESULTS OF THE SPECIALISTS' AND SCIENTISTS' RESEARCHES

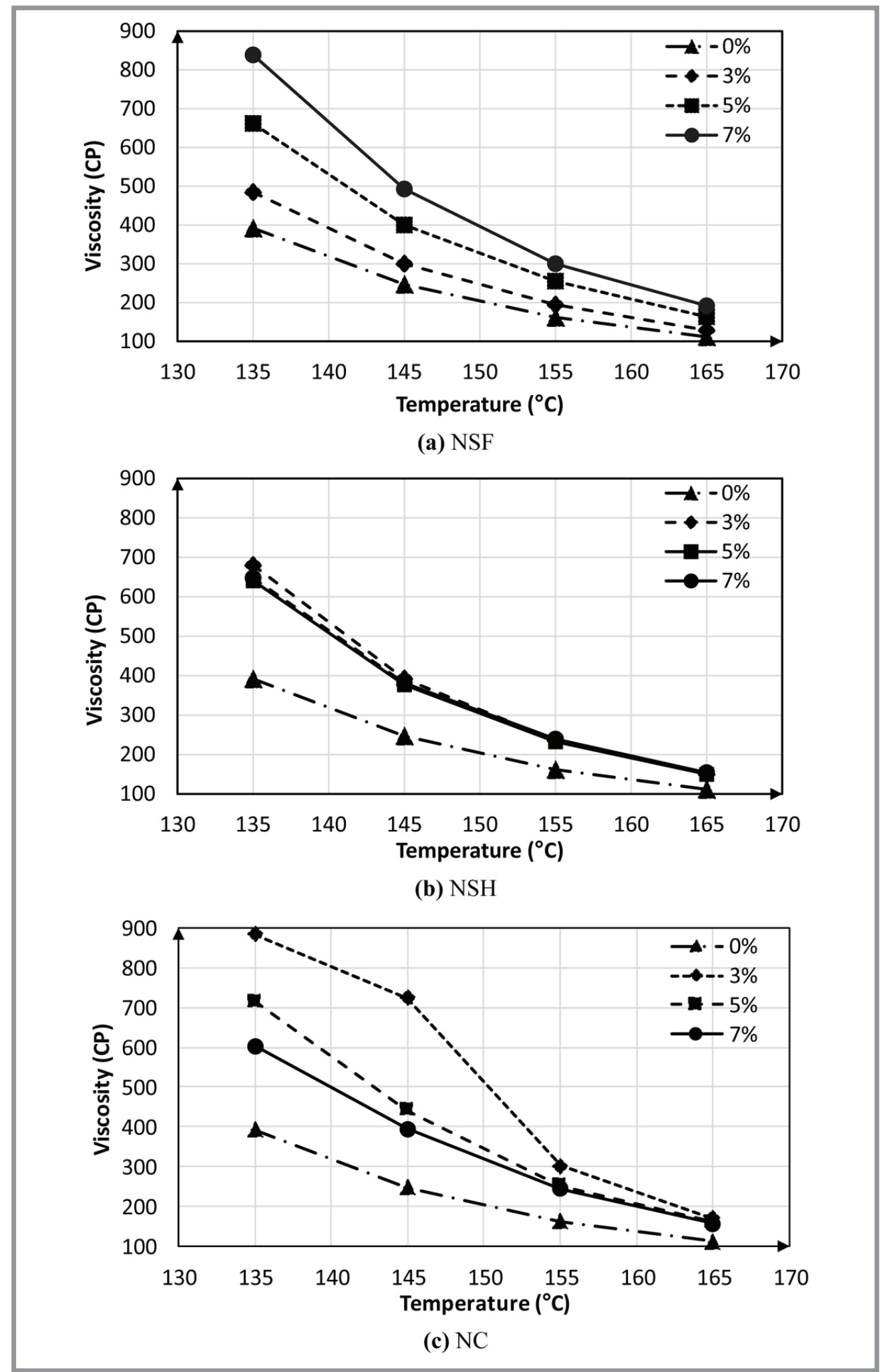

Fig. 7. Effect of Nanomaterial Type and Content on RV Viscosity at Different Temperatures 
with an increase in the NSH percentage from 3 to $7 \%$. Owing to that and other reasons such as the impurities found in NSH as well as the relatively larger crystallite size of the NSH nanoparticles, NSH was not considered for further testing.

The NC was found to increase the viscosity at $135^{\circ} \mathrm{C}$ by more than $230 \%$ at $3 \%$ as shown in Fig. 7 -c. However, increasing NC content to $7 \%$ decreased the viscosity to $153 \%$ compared to the base asphalt. At temperature as high as $165^{\circ} \mathrm{C}$, the impact of increasing the $\mathrm{NC}$ content on the viscosity is minimum.

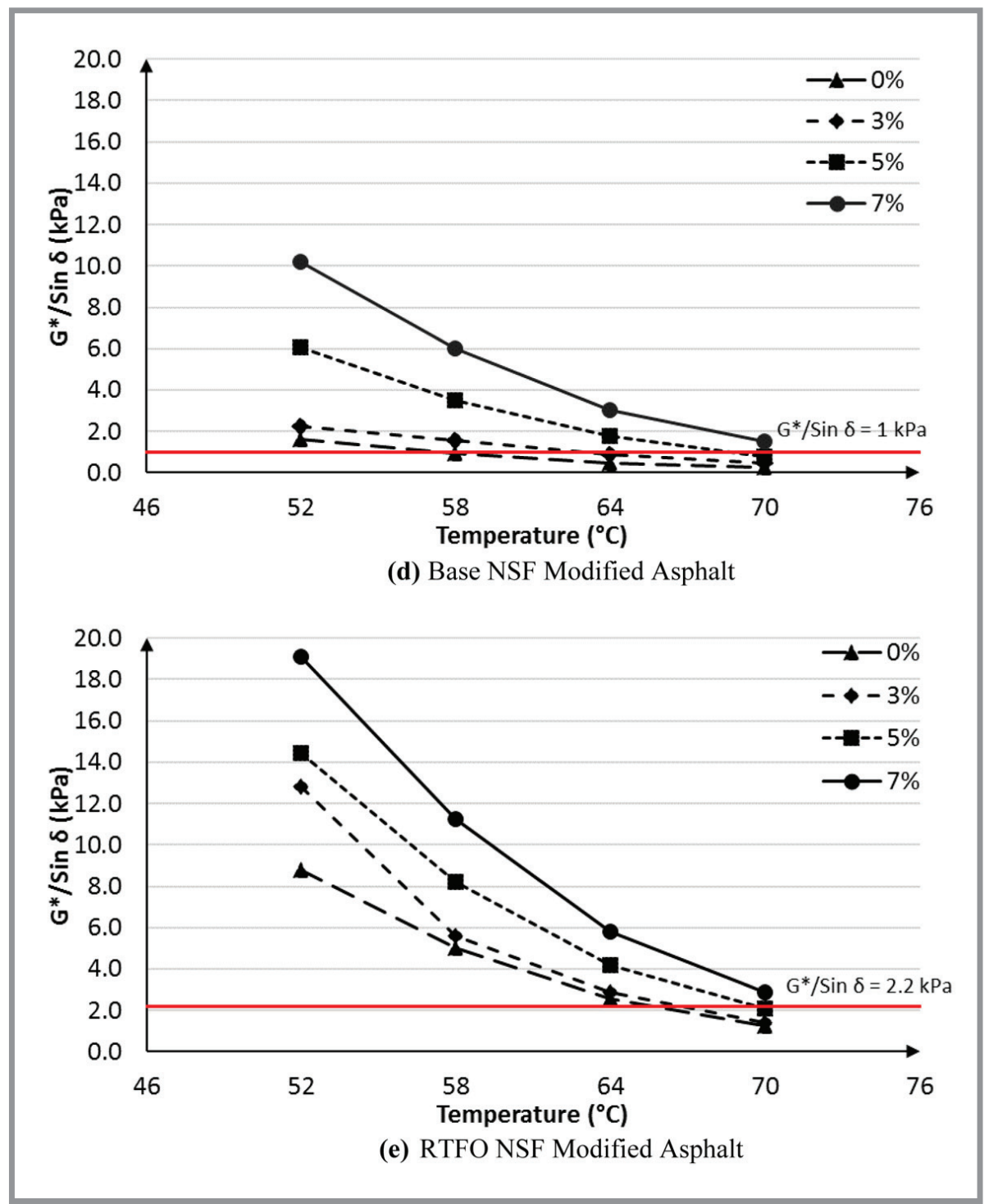

Fig. 8. DSR Results for Unaged and Aged NSF Modified-binders 


\section{Performance Properties of the Modified Asphalt Binders}

Fig. 8 and 9 depict the DSR results for the unaged and RTFO aged binders modified with different contents of NSF and NC, respectively. Fig. 8-a shows that the NSF modified unaged asphalt binder generally exhibited higher $\mathrm{G}^{*}$ and lower $\delta$ values (higher $\mathrm{G} * / \sin \delta$ ) compared to the base asphalt, which may indicate higher resistance to rutting. Moreover, the NSF increased the high temperature performance grade of the base asphalt (PG 52$\mathrm{xx})$ to a higher performance grade of (PG70-xx) as shown in Fig. (9-a and b).

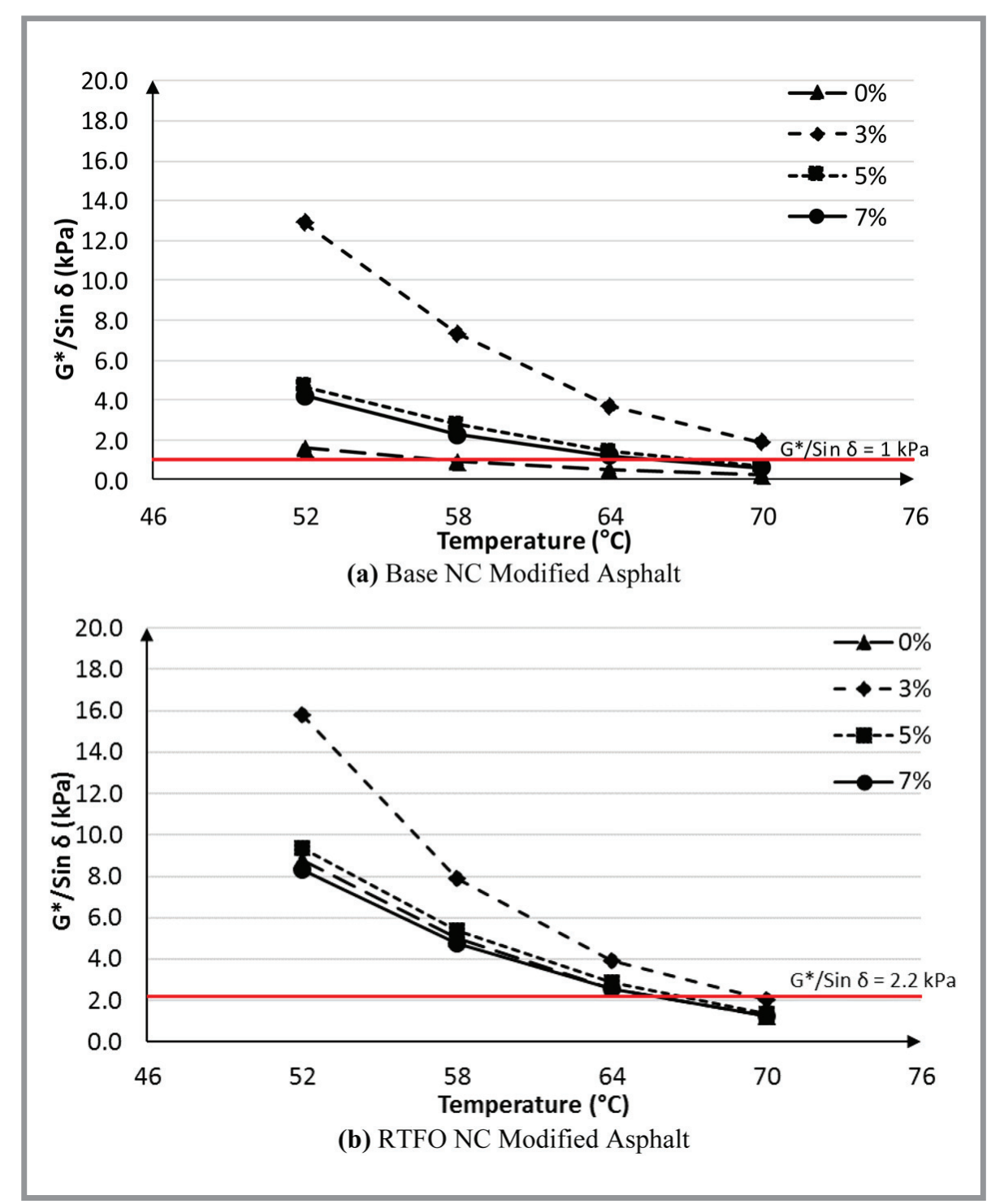

Fig. 9. DSR Results for Unaged and Aged NC Modified-binders 
This significant pump in grade was achieved by increasing the NSF to $7 \%$ by weight of the base asphalt. Only $3 \% \mathrm{NC}$ was found enough to pump the high temperature binder performance grade up to (PG64-xx) as shown in Fig. 9-a and $b$, respectively. It can be seen also from the Fig. that increasing the NC percentage above the optimum value of $3 \%$ resulted in a reduction in the performance grade compared with the $3 \%$. Mahdi et al. [7] reported similar results for NC up to $9 \%$ but with lower performance grade of PG 58-xx.

\section{Analysis of HMA Mixtures Prepared with the Modified Binders}

Fig. 10 shows the Marshall stability and loss of stability values for $0 \%, 7 \% \mathrm{NSF}$, and 3\% NC HMA mixtures. It is evident from the Fig. that the stability of the HMA mixtures prepared using nano-modified bitumen was enhanced significantly compared to those prepared using the base bitumen. It can be seen also from the same Fig. that the loss of stability when using NSF for modification, was the lowest of $6.9 \%$. While, for HMA mixtures using NC-modified bitumen, the loss of stability was the highest of $22.8 \%$ but lower than the maximum value of $25 \%$ as specified by ECP [24].

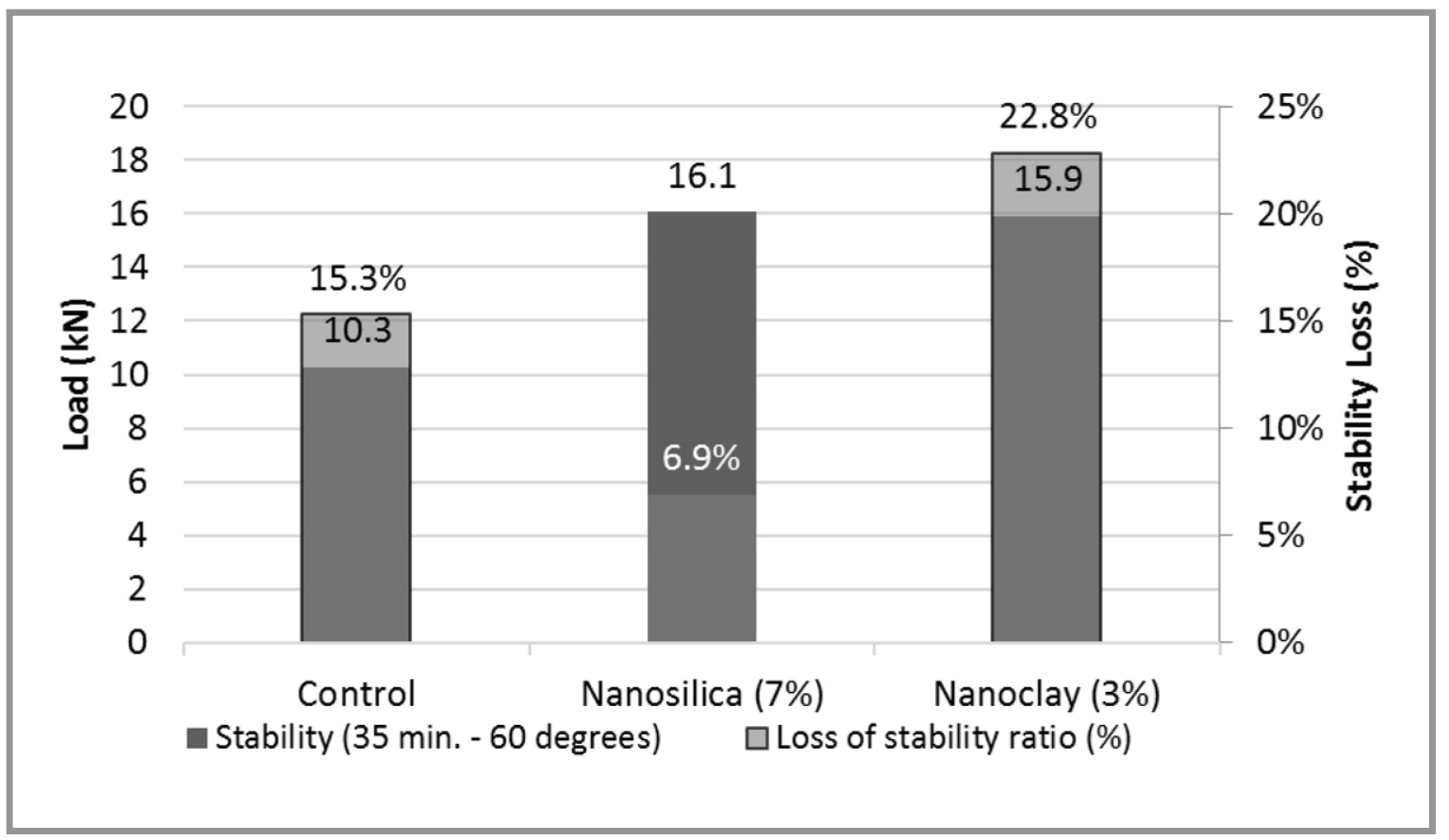

Fig. 10. Marshall stability and loss of stability of the HMA mixtures 


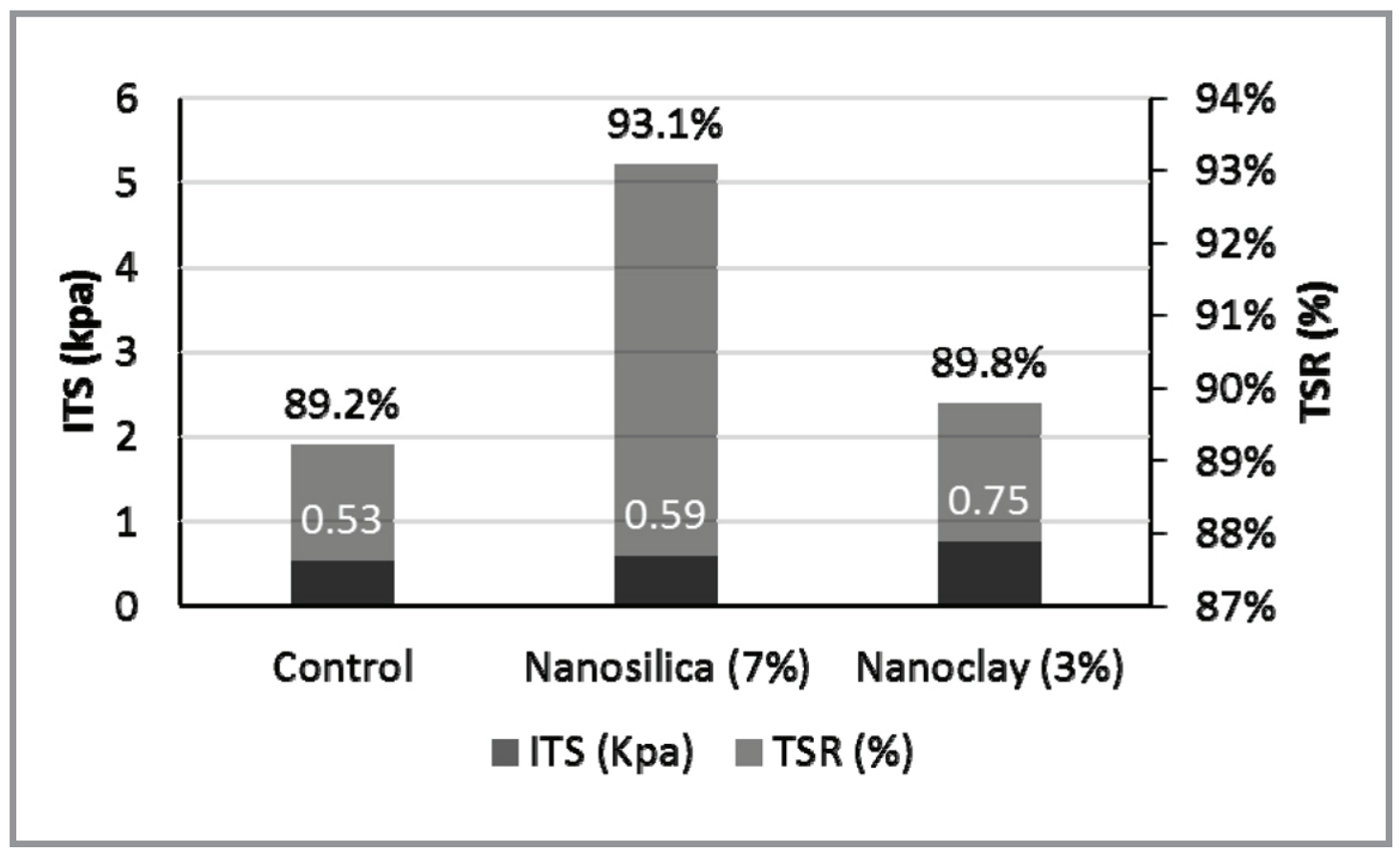

Fig. 11. Indirect tensile test and moisture susceptibility of the mixture

Fig. 11 presents the IDT strength values along with the tensile strength ratio (TSR) for nano-modified mixtures compared to the control HMA mixture. It can be seen from the Fig. that nano-modified HMA mixtures exhibited higher tensile strength than that obtained from the control HMA mixture. NC-modified HMA mixture showed the highest tensile strength,

Table 5

Summary of all Testing Results of the Three Investigated HMA Mixtures

\begin{tabular}{|l|c|c|c|c|c|c|}
\hline \multirow{2}{*}{ Test } & \multicolumn{3}{|c|}{$\begin{array}{c}\text { Marshall Stability (kN) } \\
\left(60^{\circ} \mathrm{C} \text { water bath) }\right.\end{array}$} & \multicolumn{2}{c|}{ Indirect Tensile Strength (kPa) } \\
\hline Modification & $\begin{array}{c}\text { For 35 } \\
\text { minutes }\end{array}$ & For 24 hr. & $\begin{array}{c}\text { Loss of } \\
\text { stability } \\
\text { ratio, \% }\end{array}$ & $\begin{array}{c}\text { Non- } \\
\text { Weathered }\end{array}$ & Weathered & TSR \\
\hline Control (0\%) & 10.3 & 8.7 & 15.3 & 3.6 & 3.2 & 89.2 \\
\hline NSF (7\%) & 16.1 & 15.0 & 6.9 & 4.0 & 3.8 & 93.1 \\
\hline NC (3\%) & 15.9 & 12.3 & 22.8 & 5.1 & 4.5 & 89.8 \\
\hline
\end{tabular}


however it yielded comparable TSR value of $89.3 \%$ to that for the control HMA mixture. Generally, the three HMA mixtures achieved the minimum requirement of TSR value of $75 \%$ as specified by ECP [24]. Mojtaba et al. [12] reported higher TSR values of almost $100 \%$. Table 5 summarizes the results of the all tests conducted on the HMA mixtures.

\section{CONCLUSIONS}

This study focused on the impact of using nanoclay and nanosilica to modify the asphalt binder and mixture and the following conclusions were drawn:

When using a high-speed mechanical mixer at $1500 \mathrm{rpm}, 30$ to 45 minutes of mixing time was found enough to obtain good dispersion of the nanomaterial in the hot liquid asphalt binder.

Storing the nanomodified asphalt binder for future usage up to ten days did not have a significant effect on its tested properties gained by modification in the first place.

A $3 \%$ nanoclay by weight of binder improved the performance of the binder in terms of penetration, softening point, $R V, \mathrm{G}^{*}$, and $\delta$. The binder became more suitable for hot climatic conditions. Increasing the nanoclay percentage to higher than $3 \%$ had an adverse effect on the binder properties and this was more noticeable at the $7 \%$ nanoclay.

Nanosilica synthesized from silica fume (NSF) is recommended for use in hot countries, since it decreased the penetration and increased both the softening point and the viscosity of the asphalt.

Increasing the percentage of NSF increased the high performance grade of the binder since the values of $\mathrm{G} * / \sin \delta$ continuously increased with increasing the modification percentage.

Nanosilica obtained from the chemical processing of the rice husk ash (NSH) needs more synthetization before use as a nanomaterial in order to get the full nano-effect from the material.

Asphalt resistance to permanent deformation could be improved using the right content of nano-modifier. The maximum performance grades of PG 70-xx and PG 64-xx for unaged and RTFO aged asphalts were achieved at $3 \% \mathrm{NC}$ and $7 \%$ NSH by weight of binder, respectively. Modified asphalt binders possessed higher $\mathrm{G} *$ and lower $\delta$ values than the base asphalt and consequently resistance to rutting may be improved. 
Hot asphalt mixtures prepared using 7\% NSH and 3\% NC showed much better Marshall stability compared to the control mix.

The Indirect tensile strength values of nano-modified mixtures using $7 \% \mathrm{NSF}$ or $3 \% \mathrm{NC}$ were higher than the control HMA mixture. However, HMA mixtures resistance to moisture using 3\% NC was not improved significantly.

In general, and under the light of previous conclusions, since we used cheap locally manufactured nanomaterials, we can say that economic benefit of using such materials.

\section{ACKNOWLEDGEMENTS}

The authors are grateful to Dr. Assad F. Hassan, Assistant Professor at the Chemistry Department, Faculty of Science, Damanhur University for supplying the nanosilica material produced from rice ash husk used in this research.

\section{DEAR COLLEAGUES!}

THE REFERENCE TO THIS PAPER HAS THE FOLLOWING CITATION FORMAT:

Helal E., Sherif El-Badawy, Alaa G., Zaki S.I.Evaluation of asphalt enhanced with locally made nanomaterials. Nanotehnologii v stroitel'stve $=$ Nanotechnologies in Construction. 2016, Vol. 8, no. 4, pp. 42-67. DOI: dx.doi.org/10.15828/20758545-2016-8-4-42-67. 


\section{References:}

1. Sun L., Guan H., Ge Q. Research on the Performance of Asphalt Modified by SBS Rubber and Carbon Nanotube. in Applied Mechanics and Materials. 2011. Trans Tech Publ.

2. Hao X.H., Zhang A.Q., Yang W. Study on the Performance of Nano Calcium Carbonate Modified Asphalt Concrete AC-13. in Advanced Materials Research. 2012. Trans Tech Publ.

3. Amirkhanian A.N., Xiao F., Amirkhanian S.N. Characterization of Unaged Asphalt Binder Modified with Carbon Nano Particles. International Journal of Pavement Research and Technology, 2011. 4(5): p. 281-286.

4. Zhang $M$. Strength Properties of Pavement Concrete Containing Nano-Particles. in Electric Technology and Civil Engineering (ICETCE), 2011 International Conference on. 2011. IEEE.

5. Su Q. et al. Study on how to Improve Asphalt-Modified with SBS-Added Carbon-Nanotubes-Material. in Advanced Materials Research. 2012. Trans Tech Publ.

6. Nazzal M.D. et al. Fundamental Characterization of Asphalt Clay Nanocomposites. Journal of Nanomechanics and Micromechanics, 2012. 3(1): p. 1-8.

7. Mahdi L.M. et al. Effect of Short Term Aging on Organic Montmorillonite Nanoclay Modified Asphalt. Indian Journal of Science and Technology, 2013. 6(10): p. 5434-5442.

8. Jahromi S.G., Khodaii A. Effects of Nanoclay on Rheological Properties of Bitumen Binder. Construction and Building Materials, 2009. 23(8): p. 2894-2904.

9. Goh S.W. et al. Effect of Deicing Solutions on the Tensile Strength of Micro-or Nano-modified Asphalt Mixture. Construction and Building Materials, 2011. 25(1): p. 195-200.

10. Ping L., Yunlong L. Review on Nano Modified Asphalt. Applied Mechanics \& Materials, 2014. 587: p. 1220-1223.

11. Sarsam S.I. Impact of Nano Materials on Rheological and Physical Properties of Asphalt Cement. International Journal of Advanced Materials Research, 2015. 1(1): p. 8-14.

12. Mojtaba G. et al. Modification of Stone Matrix Asphalt with Nano-SiO2. J Basic Appl Sci Res, 2012. 2(2): p. 1338-1344.

13. Arabani M., Haghi A., Tanzadeh R. Laboratory Study on the Effect of $\mathrm{Nano}^{-\mathrm{SiO}_{2}}$ on Improvement Fatigue Performance of Aged Asphalt Pavement. in 4th International Conference on Nanostructures, Kish Island, IR Iran. 2012. 
14. Sarsam S. Improving Asphalt Cement Properties by Digestion with Nano Materials. Research and Application of Material Journal,(RAM), 2013. 1(6): p. 61-64.

15. Van de Ven M., Molenaar A., Besamusca J. Nanoclay for Binder Modification of Asphalt Mixtures. in Proceedings of the 7th International RILEM Symposium on Advanced Testing and. Characterization of Bituminous Materials, Rhodes, Greece. 2009.

16. Yazdani A., Pourjafar S. Optimization of Asphalt Binder Modified with PP/SBS/ Nanoclay Nanocomposite using Taguchi Method. in Proceedings of World Academy of Science, Engineering and Technology. 2012. World Academy of Science, Engineering and Technology.

17. ASTM C39 / C39M-15a, Standard Test Method for Compressive Strength of Cylindrical Concrete Specimens, ASTM International, West Conshohocken, PA, 2015.

18. Zhang Z.P. et al. The Influence of Nano-Montmorillonite on High Temperature Performance of Asphalt. in Advanced Materials Research. 2014. Trans Tech Publ.

19. El-Shafie M., Ibrahim I., El Rahman A.A. The Addition Effects of Macro and Nano Clay on the Performance of Asphalt Binder. Egyptian Journal of Petroleum, 2012. 21(2): p. 149-154.

20. Tang X.D. et al. Performance Evaluation of Nano-Montmorillonite/SBS Modified Asphalt Paving Mixtures. in Materials Science Forum. 2011. Trans Tech Publ.

21. Hassan A. et al. Synthesis and Characterization of High Surface Area Nanosilica from Rice Husk Ash by Surfactant-Free Sol-Gel Method. Journal of sol-gel science and technology, 2014. 69(3): p. 465-472.

22. ASTM E2456-06(2012), Standard Terminology Relating to Nanotechnology, ASTM International, West Conshohocken, PA, 2012.

23. Hall B., Zanchet D., Ugarte D. Estimating Nanoparticle Size from Diffraction Measurements. Journal of applied crystallography, 2000. 33(6): p. 1335-1341.

24. Egyptian Code for Urban and Rural Roads (2008) - Part 4: Road Material and its Tests, Table 1-3-2. Housing and Building National Research Center. p. 28.

25. ASTM D5-06, Standard Test Method for Penetration of Bituminous Materials, ASTM International, West Conshohocken, PA, 2006.

26. ASTM D36-95(2000)e1, Standard Test Method for Softening Point of Bitumen (Ring-and-Ball Apparatus), ASTM International, West Conshohocken, PA, 2000.

27. ASTM D4402 / D4402M-15, Standard Test Method for Viscosity Determination of Asphalt at Elevated Temperatures Using a Rotational Viscometer, ASTM International, West Conshohocken, PA, 2015. 
28. ASTM D7175-08, Standard Test Method for Determining the Rheological Properties of Asphalt Binder Using a Dynamic Shear Rheometer, ASTM International, West Conshohocken, PA, 2008.

29. ASTM D2872-12e1, Standard Test Method for Effect of Heat and Air on a Moving Film of Asphalt (Rolling Thin-Film Oven Test), ASTM International, West Conshohocken, PA, 2012.

30. Hasan Z. et al. Evaluation of Different Conditions on the Mixing Bitumen and Carbon Nano-tubes. International Journal of Civil \& Environmental Engineering IJCEE-IJENS, 2012. 12(06): p. 53-59.

31. ASTM D6927-15, Standard Test Method for Marshall Stability and Flow of Asphalt Mixtures, ASTM International, West Conshohocken, PA, 2015.

32. ASTM D1559-89, Test Method for Resistance of Plastic Flow of Bituminous Mixtures Using Marshall Apparatus, ASTM International, West Conshohocken, PA, 1998.

33. ASTM D6931-12, Standard Test Method for Indirect Tensile (IDT) Strength of Bituminous Mixtures, ASTM International, West Conshohocken, PA, 2012.

34. ASTM D4867 / D4867M-09(2014), Standard Test Method for Effect of Moisture on Asphalt Concrete Paving Mixtures, ASTM International, West Conshohocken, PA, 2014. 
Автор: ХЕЛАЛ ЭЗАТ, студент, Университет Эль-Мансуры, ул. Элгомгория, Дакахлия, 35516, Эль-Мансура, Египет, helo_ez@yahoo.com;

Автор: ШЕРИФ БАДАВИ, доцент, Университет Эль-Мансуры, ул. Элгомгория, Дакахлия, 35516, Эль-Мансура, Египет, sbadawy@mans.edu.eg;

Автор: АЛА ГАБР, доцент, Университет Эль-Мансуры, ул. Элгомгория, Дакахлия, 35516, Эль-Мансура, Египет, eng-alaa1400@mans.edu.eg;

Автор: СААИД ЗАКИ, доцент Института материаловедения и контроля качества, Национальный исследовательский центр жилищного строительства, Египет; ул. Тахир, 87, Каир, Египет, 11511, a/я 1770, saaid_zaki@yahoo.com

\section{ПОКАЗАТЕЛИ БИТУМНОГО ВЯЖУЩЕГО С ДОБАВКАМИ НАНОРАЗМЕРНЫХ МОДИФИКАТОРОВ}

\section{АННОТАЦИЯ К СТАТЬЕ (АВТОРСКОЕ РЕЗЮмЕ, РЕФЕРАТ):}

Работа направлена на исследование свойств битумного вяжущего, модифицированного наноразмерными алюмосиликатами и нанокремнеземом. При выполнении экспериментальных исследований был использован нанокремнезем как неорганического, так и органического происхождения. В качестве основной управляющей рецептурной переменной использована концентрация наноразмерных объектов. Полученные эмпирические результаты свидетельствуют, что модификация битумного вяжущего нанокремнеземом неорганического происхождения, вводимом в количестве менее $3 \%$, сопровождается не только увеличением вязкости композиции, но и повышением показателей эксплуатационных свойств: наблюдается рост барьерных показателей (снижение проницаемости) и температуры размягчения; при увеличении концентрации указанного модификатора свыше 3\% барьерные показатели начинают снижаться. При использовании наноразмерных алюмосиликатов концентрационные зависимости исследованных показателей имеют аналогичный вид для концентраций менее $3 \%$; за пределами этого диапазона как вязкость, так и температура размягчения снижаются вместе с увеличением концентрации нанодисперсных алюмосиликатов. Сравнительный анализ влияния нанокремнеземов неорганического и органического происхождения позволяет сделать заключение, что введение последних неэффективно, начиная с концентраций более $3 \%$. В целом, о существенном повышении показателей вяжущего при введении исследованных нанодисперсных материалов свидетельствуют результаты, полученные с использованием различных методов, в частности - динамических испытаний на сдвигоустойчивость и теста Маршала.

Ключевые слова: модифицированное битумное вяжущее, наноматериалы, наноалюмосиликаты, нанокремнезем.

DOI: dx.doi.org/10.15828/2075-8545-2016-8-4-42-67 


\section{МАШИНОЧИТАЕМАЯ ИНФОРМАЦИЯ О СС-ЛИЦЕНЗИИ в МЕТАДАННЫХ СТАТЬИ (НTML-КОД):}

$<$ a rel=»license» href=»http://creativecommons.org/licenses/by/4.0/»><img alt=» Лицензия CreativeCommons» style=» border-width:0»src=»https://i.creativecommons.org/l/by/4.0/88x31.png» $/></ \mathrm{a}><$ br $/>$ Произведение "<spanxmlns:dct=»http://purl.org/dc/terms/» href=»http://purl.org/dc/dcmitype/Text» property=»dct:title» rel=»dct:type» $>$ Показатели битумного вяжущего с добавками наноразмерных модификаторов $</$ span $>$ » созданное автором по имени <a xmlns:cc=»http://creativecommons.org/ns\#» href=»Нанотехнологии в строительстве. -2016 .

- Tом 8, № 4. - C. 42-67. - DOI: dx.doi.org/10.15828/2075-8545-2016-8-4-42-67» property=»cc:attributionName» rel=»cc:attributionURL»> Хелал Э., Шериф Б., Ала Г., Заки С. </a>, публикуется на условиях <a rel=»license» href=»http://creativecommons.org/licenses/by/4.0/»>лицензии CreativeCommons "Attribution» ( ААрибуция») 4.0 Всемирная $</ \mathrm{a}>$. $<$ br $/>$ Основано на произведении с $<$ a xmlns:dct=»http://purl.org/dc/terms/» href=»http://nanobuild.ru/ru_RU/ nanobuild-4-2016/»rel=»dct:source»>http://nanobuild.ru/ru_RU/nanobuild-4-2016/</a >.<br />Разрешения, выходящие за рамки данной лицензии, могут быть доступны на странице $<$ a xmlns:cc=»http://creativecommons.org/ns\#» href=»saaid_ zaki@yahoo.com»rel=»cc:morePermissions»>saaid_zaki@yahoo.com $</ a>$.

\section{УВАЖАЕМЫЕ КОЛЛЕГИ! \\ ПРИ ИСПОЛЬЗОВАНИИ МАТЕРИАЛА ДАННОЙ СТАТЬИ ПРОСИМ ДЕЛАТЬ БИБЛИОГРАФИЧЕСКУЮ ССЫЛКУ НА НЕЁ:}

Хелал Э., Шериф Б., Ала Г., Заки С. Показатели битумного вяжущего с добавками наноразмерных модификаторов // Нанотехнологии в строительстве. 2016. - Tом 8, № 4. - C. 42-67. - DOI: dx.doi.org/10.15828/2075-8545-2016-84-42-67.

\section{Dear Colleagues!}

THE REFERENCE TO THIS PAPER HAS THE FOLLOWING CITATION FORMAT:

Helal E., Sherif El-Badawy, Alaa G., Zaki S.I. Evaluation of asphalt enhanced with locally made nanomaterials. Nanotehnologii v stroitel'stve = Nanotechnologies in Construction. 2016, Vol. 8, no. 4, pp. 42-67. DOI: dx.doi.org/10.15828/20758545-2016-8-4-42-67. (In Russian). 